\title{
Makedonya'nın Nato Üyeliğinin Türkiye ve ABD Desteği Kapsamında Tartışılması
}

\section{Asiye Şimşek ${ }^{1}$}

\section{ÖZET}

Makedonya; Yugoslavya'nın dağılmasının ardından 8 Eylül 1991'de diğer devletlerden farklı olarak çatışmalar yaşamaksızın bağımsızlığını ilan etmiştir. Bağımsızlık ilanının ardından devlet politikası olarak uluslararası kuruluşlara üyeliğe son derece önem vermiştir. Üye olmak istediği en önemli kuruluşlardan biri de NATO'dur. NATO'nun aday ülkeler için uyguladığı Barış için Ortaklık (PfP) programına 1995 yılında katılıp istenen tüm reformları gerçekleştirmesine ve NATO'nun dünyanın değişik yerlerinde gerçekleştirdiği askeri operasyonlara destek vermesine rağmen Yunanistan vetosu ${ }^{2}$ nedeniyle üyeliğe kabul edilmemektedir. Ancak bu üyeliğe destek veren ülkeler de vardır. Bu da Makedonya'yı cesaretlendirmektedir. Bu çalışmanın amacı da; Makedonya'nın NATO üyeliğinin araştırılması ve bu üyeliğe destek veren Türkiye ve ABD açısından konunun tartışılmasıdır.

Anahtar Kelimeler: Makedonya, NATO, Türkiye, ABD.

\footnotetext{
${ }^{1}$ Yalova Üniversitesi Uluslararası İlişkiler Bölümü Yüksek Lisans Öğrencisi.

2 Geçmişi M.Ö. 700’lü yıllara dayanan Makedonya Cumhuriyeti ile Yunanistan arasındaki isim sorunu; 1991 yılında Makedonya'nın Yugoslavya Federasyonu'ndan "tam egemen” olarak bağımsızlığını ilan etmesinden sonra ortaya çıkmıştır. Makedonya'nın geçmişini; kendi ataları olarak kabul ettikleri Büyük İskender'e kadar uzandığını savunan Yunanistan, bu sebepten ötürü Makedonya'yı Helen geçmişe sahip bir devlet olarak görmektedir. Fakat bu duruma Makedonya Cumhuriyet'i yetkilileri şiddetle karşı çıkmaktadır. Asıl Makedon ırkının, Slav ırkından geldiğini ve geçmişte hiçbir zaman Yunanca konuşmadıklarını iddia etmektedirler. Bugün ortada olan sorunun başlıca sebebi Yunanistan'ın gelecekte Makedonya tarafından olabilecek olası bir toprak talebini şimdiden bertaraf etmektir. Yunanistan'ın kuzey komşusu Makedonya Cumhuriyeti ile olan sınırına yakın bir bölgede aynı isme sahip olan Makedonya bölgesi sebebiyle; Yunanistan, Makedonya Cumhuriyeti'nin anayasal ismini tanımayarak kendisini güvende hissetmektedir.
} 


\section{Asiye Şimşek}

\section{GíRiș}

Makedonya 1992'deki bağımsızlık ilanından itibaren uluslararası kuruluşlara üyeliğe son derece önem vermiş; bunu kalkınma ve gelişmesinin temel prensipleri arasında görmüştür. Bu kuruluşların en önemlilerinden biri olan NATO'ya; Ulusal güvenliğini ve devletin politik istikrarını sağlamak için üye olmayı istemektedir. Bu kuruluşa üyelik için gerekli tüm reformları gerçekleştirmiş, askeri destek vermiş ve Güneydoğu Avrupa Barış Operasyonu Birimi (SEEBRIG) bünyesinde de yer almış ancak Yunanistan'la yaşadığı İsim Sorunu'ndan dolayı üyeliği kabul edilmemiştir. Bu üyeliğin kabulü için dış politikada desteğe ihtiyacı vardır. Türkiye ve ABD de bu desteği sonuna kadar vermektedir. Her iki ülke de hem kendilerinin NATO üyesi olmaları hem de dıs politikalarında Balkan Bölgesinin istikrarlı ve huzurlu olmasına önem vermeleri dolayısıyla Makedonya için kilit önemdedirler.

ABD; Makedonya'nın NATO üyeliğini Balkan politikası çerçevesinde ele almaktadır. Bu yüzden ABD’nin Balkan politikasının anlaşılması önemlidir. ABD'nin Yeni dönem dış politikasında Balkanlar öncelikli bir alan değildir. $\mathrm{ABD}$ bu alanı $\mathrm{AB}$ 'nin sorumluluk sahası olarak görmekte ve bölgedeki huzursuzluğun giderilmesi amacıyla bölgeyle askeri açıdan ilgilenmektedir. Bölgedeki ciddi huzursuzluklarda bölgenin sorunlarının antlaşmalarla ya da uluslararası kuruluşlara üyeliklerle çözülmesi konusunda yardımcı olmaktadır. Bu yüzden bölge ülkelerine NATO üyeliği konusunda gerekli desteği vermektedir. Makedonya'nın NATO üyeliği konusunu da bu kapsamda değerlendirmek gerekir. ABD; Bu üyeliğe destek vererek Makedonya'nın içinde bulunan Arnavut ve diğer etnik azınlıklar arasındaki çatı̧̧maları önlemeye çalışmakta böylece burada çıkacak bir Arnavut sorununun diğer bölge ülkelerinde yaşayan Arnavutları da ayaklandırmasına karşı önlem almaktadır. Bu önlem sayesinde bölgedeki huzursuzlukların önüne geçmekte askeri gücünü de kendisi için hayati derecede önemli gördüğü Ortadoğu ve Asya gibi alanlarda kullanmaktadır. Üyeliğe destek vermesinin ikinci nedeni ise bölgedeki son krizlerde yapıcı rol üstlenip büyümesinin önüne geçerek bölgedeki prestijini artırmak istemesidir. Bu da bölgede çıkacak herhangi bir huzursuzlukta desteğine başvurulması yani bölgenin abisi rolünü üstleneceği anlamına gelmektedir. Üyeliğe desteğinin üçüncü ve son nedeni ise az da olsa ekonomiktir. Makedonya'nın Arnavut Krizinin önüne geçerek Makedonya'yla sorunlarını 1990'lı yıllarda çözen Bulgaristan ile Makedonya Arnavutlarını destekleyen Arnavutluk arasında da olası bir savaş riskini ortadan kaldırmasıdır. Böylece Amerikan ve İngiliz petrol şirketleri tarafindan desteklenen Burgaz-Makedonya-Vlore (AMBO) petrol boru hattı projesinin hayata geçmesinin de önünü açmaktadır.

Türkiye de ABD gibi Makedonya'nın üyeliğini bölge politikası kapsamında değerlendirmektedir. Yalnız ABD'nin aksine Balkanları hayati çıkar alanı olarak görmekte; bölgede meydana gelen her türlü olumsuzluktan tarihi ve jeopolitik yakınlık nedeniyle etkilenmektedir. Çünkü Türkiye için Balkanlar Osmanlı bakiyesidir ve bu bölgede meydana gelecek her türlü olumsuzluktan etkilenecektir. Bu yüzden bu bölgenin huzur ve istikrarı son derece önemlidir. $\mathrm{Bu}$ huzur ve istikrar da uluslararası kuruluşlara üyelikle gerçekleşecektir. Türkiye bu kapsamda düşünüp bölge ülkelerinin NATO’ya üyeliğini sonuna kadar desteklemektedir. Bu desteğin diğer bir nedeni ise NATO politikalarıla ilgilidir. NATO 'açık kapı' politikası gereği birden çok defa genişlemiştir. Türkiye de bu genişlemenin tüm bölge ülkelerini içine alacak şekilde gerçekleşmesini istemektedir. Makedonya'nın üyeliğine destek vermesinin son nedeni ise Makedonya'da yaşayan Türklerdir, çünkü ülkede yaşanacak olan herhangi bir huzursuzluktan doğrudan etkileneceklerdir. Bu da ya Türkiye gerçekleşecek olası göçler yoluyla ya da Türkiye'de bulunan akrabaları yoluyla Türkiye'yi etkileyecektir.

\section{NATO'nun Kuruluşu ve Genişleme Politikaları}

İki dünya savaşı; Atlantik'e veya Atlantik bölgesi içindeki iç denizlere sınırı olan herhangi bir veya birkaç devlete yapılan bir saldırı sonrasında Kuzey Atlantik bölgesinin tehlikeye düştüğünü ve dünyanın bu Batı bölgesinde yaşanan herhangi bir çatışmanın da çok tehlikeli sonuçlara yol açarak her tarafa sıçradığını, uzak veya yakın bütün ulusları etkilediğini göstermiş̧ir. Bölgede yaşayan devletler, bu gerçekten hareket ederek, bölgelerinin ortak kaderinin farkına varmışlardır. ${ }^{3}$

Batılı ülkelerin egemenliklerine doğrudan yönelen tehditler, Çekoslovakya'daki 1948 darbesi, 1948'de Berlin'in SSCB tarafında abluka altına alınması gibi gelişmeler, Belçika, Fransa, Lüksemburg, Hollanda ve İngiltere'nin, ortak bir savunma sistemi kurmak ve güvenliklerine yönelik ideolojik, siyasi ve askeri tehditlere direnecek şekilde aralarındaki bağları kuvvetlendirmek amacıyla bir antlaşma imzalamalarına yol açmışıtır. Mart 1948'de imzalanan Brüksel Antlaşmasıyla kurulan Batı Avrupa Savunma Örgütü, İkinci Dünya Savaşı ertesinde Batı

\footnotetext{
${ }^{3}$ Franz Josef Strauss, “An Alliance of Continent”, International Affairs, C. 41, No. 2, Nisan 1965, s. 193.'dan Muharrem Gürkaynak, "ikinci Dünya Savaşı Sonrasında Avrupa'da Savunma ve Güvenlik", (Yayımlanmış doktora tezi, Danışman Prof. Dr. Ersin Onulduran, Ankara Üniversitesi Sosyal Bilimler Enstitüsü, 2004), ss. 47,48.
}

BARIŞ ARAŞTIRMALARI VE ÇATIŞMA ÇÖZÜMLERi DERGisi http://dergi.cicr.org.tr/ 
Avrupa'nın güvenliğinin yeniden yapılandırılması yönündeki ilk adımı teşkil etmiştir. Bu ilk adım ve ardından meydana gelen olaylar neticesinde Kuzey Atlantik Antlaşması Örgütü’nün kurulmasına karar verilmiştir. ${ }^{4}$

4 Nisan 1949'da ABD, Belçika, Danimarka, Fransa, Hollanda, İngiltere, İtalya, İzlanda, Kanada, Lüksemburg, Norveç ve Portekiz Washington D.C.'de bir araya gelerek bu yeni dünyadaki güvenlik ve askeri tehlikelere karş1 Kuzey Atlantik Antlaşması' nı imzalamışlardır. Fakat, bu antlaşmanın uluslararası bir örgüte dönüşmesi ve savunma konusunda bir ittifak stratejisinin belirlenmesi Kore Savaşı nedeniyle olmuştur. 25 Haziran 1950'de Kuzey Kore'nin Güney Kore'ye saldırmasıyla başlayan savaş, dünya ve Avrupa güvenliğine karşı Sovyetlerin sadece politik değil, aynı zamanda askeri bir tehdit oluşturduğu inancını Batı bloğunda pekiştirdi. Sovyetler Birliği, Avrupa'yı doğrudan işgal edebilir veya Kuzey Kore birliklerini Güney Kore'ye karşı kışkırttığı gibi, Doğu Alman "polis gücünü" de Batı Almanya'ya saldırması için destekleyebilir ve böylece Avrupa' da istikrarı dolaylı yoldan bozabilirdi. Sovyet tehdidinin. bu şekilde algılanmasıyla New York'ta toplanan Kuzey Atlantik Konseyi, Avrupa'da askeri bir gücün oluşturulmasına karar verdi. Avrupa Müttefik Komutanlığı kuruldu, General Dwight D. Eisenhower ilk Avrupa Müttefik Yüksek Komutanı olarak atandı ve 2 Nisan 1951 tarihinde Avrupa Müttefik Kuvvetleri Karargahı Fransa'daaçıldı. Böylece, Kuzey Atlantik Antlaşması,askeri-politik bir örgüt haline getirildi. ${ }^{5}$

NATO; üye devletler arasında sürekli danışma, görüşme ve diyalog yoluyla işbirliğini pekiştirmektedir. Antlaşmaya göre üye ülkeler; demokrasi, bireysel özgürlük ve hukukun üstünlüğü temelinde bütün halkların özgürlüklerini, ortak miraslarını ve uygarlıklarını korumaya kararlıdırlar, ayrıca, NATO; bir saldırı veya saldırı tehdidine karşı üyelerini savunmaya ve bu amaçla, bir üyesine yapılacak saldırının tüm üyelerine yapılmış varsayılacağı ilkesine dayanan bir örgüttür. ${ }^{6}$ Örgütün amacı, Avrupa'nın güvenliği için ABD’nin katkısını sağlamak, SSCB'ye karşı güvenliği sağlamak ve Almanya'nın yeniden silahlandırılmasını bölgeye tehdit oluşturmadan gerçekleştirmektir. ${ }^{7}$ Soğuk Savaş sonrasında da Atlantik ötesi güvenlik işbirliğinde NATO'nun temel işbirliği organizasyonu olarak kalması ancak dünyada sürekli değişime uğrayan güvenlik anlayışına göre yeniden tanımlanması hedeflenmiştir ${ }^{8}$ ve bu dönemin kapanmasından sonra NATO'nun ülkeler arasındaki ilişkileri düzenleme özelliği, genişleme süreciyle birlikte yeniden ön plana çıkmıştır. ${ }^{9} 12$ ülke tarafından kurulan birlik geçirdiği 6 genişleme süreci sonucu bugün 28 üyeli bir örgüte dönüşmüştür. Bu durum, İttifak'ın genişlemesinin dinamik ve devam eden bir süreç olduğunu göstermektedir. ${ }^{10}$

NATO’nun Soğuk Savaş sonrası genişleme ve küresel işbirliği politikasını üç kategoride toplamak mümkündür. Birinci kategoride, NATO’ya tam üyelik yolu ile katılım sürecine giren ülkeler yer almaktadır. Bu kategorideki ülkelerin Avrupa sınırlarında olmaları ve kendi iradeleri ile üyelik arzusunu ortaya koymaları gerekmektedir. Üyelik için siyasi iradenin ortaya konması ile başlayan ilişki ve tam üyeliğe götüren "Üyelik İçin Aksiyon Planı" sürecinde gerekli kriterleri yerine getiren ülkeler NATO'ya tam üye olma hakkına sahip olmaktadırlar. Bu çerçevede, soğuk savaş sonrası NATO üç defa tam üyelik yolu ile genişlemiştir. Soğuk savaş sonrası birinci genişleme 8 Temmuz 1997'de Madrid Zirvesinde, Çek Cumhuriyeti, Polonya ve Macaristan İttifaka katılım müzakerelerine davet edilmişlerdir ve katılım süreci başlamıştır. Bu ülkeler 12 Mart 1999'da Vaşington'da katılım protokolünün imzalanması ile ittifaka dahil olmuşlardır. İkinci genişleme kararı ile 21-22 Kasım 2002 tarihlerinde Prag Zirvesinde alınmıştır. Bu zirve ile Bulgaristan, Estonya, Letonya, Litvanya, Romanya, Slovakya ve Slovenya'nın NATO’ya tam üye olarak katılmaları kararı alınmış ve üyelik süreci 2005 yılı başında gerçekleşmiştir. Üçüncü genişleme süreci; Arnavutluk, Hırvatistan ve Makedonya'dan oluşan üç ülke ile başlatılmış ve üyelik kriterlerini yerine getiren bu ülkelerin tam üyeliklerine Nisan 2008 tarihinde yapılan Bükreş Zirvesinde karar verilmiştir. Arnavutluk ve Makedonya bu zirvede tam üyelik hakkı kazanırken, Makedonya'nın üyeliği Yunanistan'ın Makedonya ismine itirazı sebebi ile askıda kalmıştır ${ }^{11}$.

\footnotetext{
4 Türkiye Cumhuriyeti Dışişleri Bakanlığı, "Türkiye'nin Güncel NATO Konularına İlişkin Görüşleri” htttp://www.mfa.gov.tr/nato-tarihce.tr.mfa

5 Nejat Doğan, "Nato'nun Örgütsel Değişimi, 1949- 1999:Kuzey-Atlantik İttifakından Avrupa-Atlantik Güvenlik Örgütüne” Ankara

Üniversitesi, SBF Dergisi, 60-3, s.73

${ }^{6}$ Türkiye Cumhuriyeti Dışişleri Bakanlığı, “Türkiye'nin Güncel NATO Konularına İlişkin Görüşleri” http://www.mfa.gov.tr/nato-tarihce.tr.mfa

${ }^{7}$ Belgin Akçay ve İlke Göçmen (Ed.), Avrupa Birliği; Tarihçe, Teoriler, Kurumlar ve Politikalar, Güncellenmiş 2. Baskı, Ankara: Seçkin Yayıncılık, 2012, s.46

${ }^{8}$ Yakup Beriş ve Aslı Gürkan (Haz.), Türk- Amerikan iliş̧kilerine Bakış:Ana Temalar ve Güncel Gelişmeler, TÜsiAD ABD Temsilciliği Değerlendirme Raporu-Temmuz 2002 (Altı Ayda Bir Güncellenir, Son Güncelleme: Ocak 2003)

9 Zeynep Erşahin"Ittifakın 50. Yılında NATO-Türkiye İlişkileri" http://www.milliyet.com.tr/ozel/nato/zeynep.html

${ }^{10}$ Türkiye Cumhuriyeti Dışişleri Bakanlığı, "NATO ve Türkiye'nin Güncel NATO Konularına İlişkin Görüşleri” http://www.mfa.gov.tr/ii -natove-turkiye nin-guncel-nato-konularina-iliskin-gorusleri.tr.mfa

${ }^{11}$ Vahit Erdem, "Soğuk Savaş Sonrası NATO'nun Değişim Sürecinde Genişleme Politikası”, http://www.euractiv.com.tr/politika000110/article/vahit-erdem-soguk-savas-sonrasi-natonun-deigisim- surecinde-genisleme-politikasi-011490 (06.08.2010)
} 


\section{Asiye Şimşek}

NATO; Makedonya'nın üyeliğini; yukarıda anlatıldığı gibi ülkeyi Balkanlardaki genişleme sürecinin bir parçası olarak gördüğü için istemektedir. Bu üyeliği istemesinin ikinci sebebi ise Balkanların istikrarılya ilgilidir.

Bölgede ortaya çıkabilecek herhangi bir çatı̧̧ma kolaylıkla yayılabilir ve böylece tüm bölge, bundan olumsuz etkilenebilir. Örneğin, Kosova'daki herhangi bir olay, Makedonya ve Arnavutluktaki istikrarı etkileyebileceği gibi, bölgede iki önemli NATO üyesi olan Yunanistan ve Türkiye'yi de doğrudan güvenlik bakımından etkiler.Çünkü her iki ülkenin de Balkanlarla hem coğrafi hem de tarihi bağları vardır. Bir başka deyişle, Balkanlarda şiddet ve karışıklık meydana geldiği takdirde, bu tip olaylar, NATO'nun üyeleri arasındaki uyumu ve üyelerin bu krize gösterecekleri tepki, bizzat NATO'nun saygınlığının sınanmasına yol açacaktır. NATO, eğer böyle bir krizle baş edemezse, NATO'nun birinci görevi olan Avrupa'nın güvenliğini sağlama görevi yerine getirilmemiş olacaktır. Aynı zamanda, NATO üyeleri arasında, kriz karşısında gösterecekleri uyumun da test edilmesine yol açacaktır. ${ }^{12}$

Bugünkü Makedonya Cumhuriyeti tarihsel Makedonya'nın sadece "Pirin Makedonyası" olarak anılan bölümüdür. "Ege Makedonyası" Yunanistan, "Vardar Makedonyası" Bulgaristan tarafindan Balkan Savaşları esnasında işgal edilmiş̧ir. Sorunu daha da çetrefil hale getiren husus Sırpların bugünkü Makedonya Cumhuriyeti topraklarını "Güney Sırbistan" olarak tanımlalarıdır. Bir başka sorun Makedonya topraklarının dörtte birini oluşturan Arnavut nüfustur. Makedonya Arnavutları, Arnavutluk Kosova'da mücavir bölgelerde yaşamaktadır. Makedonya Yönetimi günün birinde Büyük Arnavutluk kurulması kaygısı taşımaktadır. Günümüzde Makedonya, tıpk1 Bosna Hersek Cumhuriyeti gibi Balkanların minyatür Bir örneğini oluşturmaktadır. Makedonya'da Bir Yandan Makedon milliyetçiliği tarihsel Makedonya projesini gündeme getirerek Bulgaristan ve Yunanistan üzerinde hak iddia ederken, Öte yandan diğerlerinin Makedonya toprakları üzerinde emelleri vardır. Bu haliyle Makedonya, irredantizmin hem nesnesi, hem öznesi konumundadır. $\mathrm{Ne}$ Kadar 2001 yılında Makedonya ile Arnavutluk arasında imzalanan Ohri Anlaşmasıyla iki Taraf arasında yakınlaşma sağlanmış ise de ülkede güven tam Olarak tesis edilememiş̧ir. ${ }^{13}$ Sonuç olarak Makedonya çok etnikli yapıya sahiptir ve bu etnik yapıların her birini destekleyen ülkelerle komşu olduğu için Makedonya'da istikrarın sağlanması son derece önemlidir. NATO da bu sebeple Makedonya'nın istikrarının Balkanların istikrarı anlamına geldiğini kabul ederek ülkenin üyeliğini istemektedir.

\section{ABD’nin Balkan Politikaları ve Makedonya'ya NATO Üyeliği İçin Verdiği Destek}

ABD'nin Balkanlardaki çıkarları dört noktada toplanabilir:

1) Bölgesel istikrar,

2) NATO'nun organizasyon olarak kriz ile baş etme yeteneği ve NATO üyelerinin kendi aralarında krize karşı gösterdikleri uyum,

3) Avrupa'nın bir bütün olarak istikrarı,

4) Rusya ile ilişkiler (Balkanlarda Sırbistan ile Rusya'nın tarihten gelen yakın ilişkileri göz önüne alınmal1). ${ }^{14}$

Balkanlar, Washington açısından başı başına bir stratejik öncelik taşımamakla beraber bölge, istikrarsızlık yaratacak sonuçlar doğurması açısından Amerikan çıkarlarını etkileyebilecek niteliktedir. Bu bağlamda ABD'nin Balkan politikasıyla ulaşmak istediği hedefler, "çatışmaların bütün bölgeyi kapsayacak bir hal almasinın ve Amerikan müttefikleri ile geçiş sürecindeki ülkeleri etkilemesinin önlenmesi; Avrupa"nın güvenlik yapısına yardımci olma rolünün yan sıra Soğuk Savaş sonrasinda NATO"nun merkezi rolünü desteklemek ve öne çıkarmak; Bosna"nın toprak bütünlügünü koruyan bir siyasal çözüm bulmak; bölgeyi istikrarsızlaştırabilecek mülteci akınını durdurmak; sivil kayıpların önüne geçmek ve bu amaçları gerçekleştirirken, zorunlu olmadıkça Amerikan kara gücünü bölgeye sokmamak" şeklinde ifade edilebilir. Bunlara bölgenin yeniden Rus etki alanına girmesine engel olmak amacı da eklenebilir. ${ }^{15}$

Balkanlar'da Soğuk Savaş sonrası dönemde en önemli gelişme şüphesiz Yugoslavya'nın kanlı bir biçimde dağılması olmuştur. Öyle ki, bu dağılma bölgedeki mevcut siyasi durumun oluşmasını tetikleyen ve bölge ülkelerinin Avro-Atlantik kurumlara üyelik süreçlerini hızlandıran ana faktörlerden biridir. Ayrıca bu dağılma sürecine girilmesi, bölgesel tansiyonu artırmış ve küresel çapta hareketliliğe neden olmuştu. Uluslararası ilişkiler literatüründe yer alan "balkanlaşma" kavramı bu dönemde de parçalanma, bölünme ve ayrışmayı simgeleyen

\footnotetext{
12 Larrabee, Stephan F. Greek Security Concerns in the Balkans, Santa Monika, RAND RP-780,1999'dan Bülent Uğrasız, “ABD'nin Soğuk Savaş Sonrası Balkan Politikası", Dokuz Eylül Üniversitesi Sosyal Bilimler Enstitüsü Dergisi, Cilt:6 Sayı:1,2004, s.296

${ }^{13}$ Hasret Çomak ve İrfan Kaya Ülger, "Balkanlarda Siyasi İstikrar ve Geleceği", BiLGESAM, Rapor NO:14,SS.18-19.

${ }^{14}$ Bülent Uğrasız, “ABD’nin Soğuk Savaş Sonrası Balkan Politikası”, Dokuz Eylül Üniversitesi Sosyal Bilimler Enstitüsü Dergisi, Cilt:6 Sayı:1,2004, s.296

${ }^{15}$ Tayyar Arı ve Ferhat Pirinççi “Soğuk Savaş Sonrasında ABD'nin Balkan Politikası” Alternatif Politika, Cilt. 3, Sayı. 1, 1-30, Mayıs 2011, s.6
} BARIŞ ARAŞTIRMALARI VE ÇATIŞMA ÇÖZÜMLERI DERGisi http://dergi.cicr.org.tr/ 
anlamıyla yeniden ünlenmiştir. Bölgede yaşanan gelişmeler Washington yönetiminin "küresel jandarma" olma iddiasına paralel olarak müdahalede bulunmasını kaçınılmaz kılmıştır. Yeni dönemde Batı Bloğu içerisinde NATO'nun yeri ve meşruiyetiyle ilgili tartışmaların gündeme gelmesi de ABD'nin NATO'yu Balkanlar'daki krizlerde fonksiyonel hale getirmesini ve meşruiyet tartışmalarını sonlandırmasını sağlayacaktı. NATO perspektifinde istediği kazanımları elde eden ABD için Balkanlar bir ölçüde siyasi, ancak öncelikli olarak askeri açıdan önemli olmuştur. ${ }^{16}$

Makedonya krizinde bu ülkenin içsel ve dışsal dinamiklerin etkili olduğu görülmektedir. Yugoslavya'dan ayrılan diğer cumhuriyetlerden farklı olarak herhangi bir savaş yaşamadan bağımsızlığını ilan eden Makedonya, çok geçmeden iç ve diş politikada bir dizi sorunla boğuşmak zorunda kalmıştı. Makedonya'nın köklü bir devlet geleneği olmamasının yanı sıra mozaiği andıran etnik-demografik yapısı içsel anlamda istikrarsızlığa yol açarken; ülkenin bağımsızlık ilanından sonra Yunanistan ile isim krizi nedeniyle ve Bulgaristan'la da Makedon dili ve kimliği bağlamında yaşadığı sorunlar ayrı bir sıkıntı kaynağı olmuştur. ABD’nin Makedonya'ya yönelik politikası ise esasında özelde Kosova sorununun genelde ise Balkanlardaki dağınık durumda olan Arnavut nüfusu konusunun gölgesinde gelişmiştir. ${ }^{17}$ ABD için Kosova sorunu birkaç açıdan önem taşıyordu. İlk olarak, bu sorun Balkanlardaki istikrarı bozma potansiyeli taşımaktadır. İkinci olarak, ABD, Kosova üzerinde denetim kurarak hem Yugoslavya hem de Makedonya'daki gelişmeleri etkileyebilmekteydi. ABD gerek Tiran yönetimi, gerekse Kosova'da İbrahim Rugova liderliğinde örgütlenen pasif direniş hareketi üzerindeki etkisini sürdürerek yaklaşık 10 yıl boyunca buradaki rahatsızlığın çatışmaya dönüşmesini engelleyebilmiştir. ${ }^{18}$

Kosova'nın bağımsızlığından en az Sırbistan kadar endişe duyan ikinci ülke Makedonya'dır. Çünkü 1999 NATO Harekâtı sonrasında Makedonya'da Arnavut milliyetçilerinin yükselen talepleri ve UÇK'nın bölgede varlığını hissettirmesi ile başlayan iç çatışmalar uluslararası kamuoyunu ciddi anlamda endişeye sevk etmişti. Makedonya'da siyasi çevreler Kosova'nın bağımsızlığının bölgede bir domino etkisi yaratacağı ve siyasi coğrafyada büyük değişikliklere yol açacağı yönünde değerlendirmeler yapmaktadır. Kosova'nın bağımsızlığının, Arnavutların yoğun olarak yaşadıkları Batı Makedonya bölgesinin Kosova ile birleşmek istemeleri ihtimali Makedonya yönetiminde derin bir kaygı uyandırmaktadır. Makedonya'nın parçalanması Balkanlarda yeni çatışmalara yol açabilecek bir potansiyel tehlike taşımaktadır. İleri aşamada Balkanlardaki tüm Arnavutların bir devlet çatısı altında "Büyük Arnavutluk"u oluşturma ideallerine sahip Arnavut milliyetçilerinin bulunduğu göz önüne alınınca sorunun Balkanların geleceği açısından ne kadar hayati bir önem taşıdığı daha iyi anlaşılacaktır. Üstelik Kosova’yı kaybeden Sırbistan'ın Bosna'daki Sırplarla birleşmek için harekete geçmek isteyebileceği ihtimali olayın karmaşıklığını ve "Balkanlar Gerçeğini”" gözler önüne sermektedir. ${ }^{19}$

Kosova politikasında etkili olan Avrupalı müttefiklerin yetersizliği ve başarısızlığı ile ilgili faktör, Washington'un Makedonya politikasında da etkili olmuştur. Ayrıca ABD'nin Makedonya'daki krize hem Balkanlardaki Arnavut varlığını rahatsız etmeden hem de Üsküp'ün istikrarına zarar vermeden bir çözüm bulması önemliydi. Nitekim Kosova krizi esnasındaki angajmanıyla Washington, Arnavutluk ve Kosova'nın yanı sıra bölgedeki diğer etnik Arnavutlarla da iyi ilişkiler kurmuş ve uzun vadeli bir stratejik ittifakın yolunu açmıştı. Ancak ABD’nin Makedonya krizine müdahil olmaması veya müdahil olup, krizi Arnavutların rahatsız olacağı bir çözümle sonlandırması, söz konusu ittifak ilişkisini zedeleyebilirdi. ${ }^{20}$

Siyasal ve stratejik nedenlerin dışında ABD’nin Makedonya politikasında ekonomik faktörler de rol oynamıştı. Zira Bulgaristan'ın Burgaz limanından Arnavutluk’un Vlore limanına kadar döşenmesi düşünülen $A M B O$ (Albanian-Macedonian-Bulgarian Oil Company) boru hattı projesi, Makedonya'dan geçmekteydi. (Philips, 2004: 183) Dolayısıyla bu hattın Makedonya'dan geçmesi, Makedonya'da istikrarsılık istenmemesi için yeterli bir sebepti. Ayrıca Makedonya'da yaşanacak bir istikrarsızlığın Arnavutluk ile Bulgaristan’ı karşı karşıya getirmesi olasılığı, İngiliz ve Amerikan petrol şirketleri tarafından desteklenen bu boru hattı projesinin başarısız olmasına yol açabilirdi. ${ }^{21}$

\footnotetext{
${ }^{16}$ Kader Özlem , “Soğuk Savaş Sonrası Dönemde ABD’nin ve Türkiye'nin Balkanlar Politikalarının Bosna Hersek, Kosova Ve Makedonya Krizleri Örneğinde İncelenmesi" Trakya Üniversitesi, Balkan Araştırma Enstitüsü,?, ss. 25-26

${ }^{17}$ Arı ve Pirinççi, a.g.e., s.s. $18-19$.

${ }^{18}$ Ahmet Yıldız ,"Türkiye'nin Balkanlarda Etkin Bir Politika İzlemesinin Avrupa Birliği ile Olan Illişkilere Etkileri”, (Yayımlanmış Yüksek Lisans Tezi, Danışman :Yrd.Doç.Dr. Ülkü Varlık, Trakya Üniversitesi, Sosyal Bilimler Enstitüsü Ocak, 2006) s. 38.

${ }_{19}$ Bilgin Çelik, Dağılan Yugoslavya Sonrası Kosova ve Makedonya Türkleri 2. Baskı, İstanbul, Gürer Yayınları, 2013,ss.57-58

${ }^{20}$ Arı ve Pirinççi, a.g.e., s.19.

${ }^{21}$ Arı ve Pirinççi, a.g.e., ss.19-20.
} 


\section{Asiye Şimşek}

Soruna Makedonya açısından bakıldığında ise; Üsküp yönetimi yaşadığı sorunlardan, bölgesel anlamda Türkiye, küresel ölçekte ise ABD'nin yardımlarıyla kurtulmaya çalışmış̧ır. Ancak Yunan lobisi nedeniyle rahat hareket edemeyen Washington Yönetimi, 1994'te Makedonya'yı FYROM adıla tanıyabilmiştir. Makedonya'daki hassas duruma istinaden Güvenlik Konseyi’nde alınan 795 sayılı karar ile ülke topraklarında konuşlanmak üzere UNPROFOR (BM Koruma Gücü) görevlendirilmişti. Aslında UNPROFOR, BM tarihinde bir ilki teşkil edecek ve savaş olmaksızın önleyici amaçlarla önceden gönderilen bir kuvvet olacaktı. Birliğin, Makedonya'nın Sırbistan-Karadağ ve Arnavutluk sınırlarına konuşlanarak ülke güvenlik ve istikrarına zarar verecek gelișmeleri rapor etmesi öngörülmüsstü. ${ }^{22}$ Güvenlik Konseyi'nin Mart 1995'te aldığı 983 sayılı karar ile UNPROFOR yerini önleyici niteliği daha ön planda olan UNPREDEP'e (BM Önleyici Barış Gücü) bırakırken; Şubat 1999'da görev süresi Çin tarafından veto edilinceye kadar ülke güvenlik ve istikrarında kilit görevler üstlenmiştir. ${ }^{23}$

Makedonya; NATO'nun aday ülkeler için uyguladığı Barış için Ortaklık (PfP) programına 1995 yılında katıldı. Bu tarihten itibaren NATO ile Makedonya arasındaki ilişkileri PfP kapsamında yürütüldü ve süreç içerisinde Makedonya, kendisinden talep edilen reformları gerçekleştirdi. Böylece örgüte katılım için aranan kriterlerin tamamını karşıladı. Makedonya, ayrıca NATO'nun dünyanın değişik yerlerinde (örneğin Bosna-Hersek, Afganistan, Lübnan) gerçekleştirdiği askeri operasyonlara mürettebatı ile katılmış ve destek vermiştir. Makedonya Güneydoğu Avrupa Barış Operasyonu Birimi (SEEBRIG) bünyesinde de yer almaktadır. Başta $A B D$ ve Türkiye olmak üzere tüm NATO üyeleri aslında Makedonya'nın örgüte katılımına sıcak bakıyor ve bu konuda Makedonya'yı destekliyor. Fakat Yunanistan Makedonya'nın NATO'ya katılmasına karşı çıkıyor. Nitekim Yunanistan'ın karşı çıkmasından dolayı Nisan 2008 Bükreş zirvesinde Makedonya'ya örgüte katılım daveti verilmedi. ${ }^{24}$

ABD Dışişleri Bakan Yardımcısı Victoria Nuland, 2014'teki Balkan turu kapsamında "Makedonya'nın NATO üyesi olması önceliğimiz" dedi. Ortak basın toplantısında NATO'nun genişleme politikası üzerine yöneltilen soruyu cevaplayan Nuland, Makedonya'nın NATO üyesi olmasının ABD olarak öncelikleri olduğunu vurguladı. Makedonya'da yaşayan farklı milletler arasındaki ilişkileri de değerlendiren Nuland, özellikle Makedon ve Arnavut halklarının bir arada ve bütünleşmiş bir şekilde yaşaması için her iki tarafın da özverili şekilde çalışması gerektiğinin önemine vurgu yaptı. Başbakan Gruevski ise Makedonya'nın NATO üyelik sürecine ABD'nin verdiği desteğin devam etmesini dilediklerini, Makedonya'nın NATO ve Avrupa Birliğine (AB) en kısa sürede üye olmak istediğini Nuland'a ilettiğini söyledi. ${ }^{25}$ Nuland'ın bu konuşması ABD'nin Makedonya'nın üyeliğine ne kadar önem verdiğini göstermesi açısından son derece önemlidir.

\section{Türkiye'nin Balkan Politikaları ve Makedonya'ya NATO Üyeliği İçin Verdiği Destek}

Türkiye, NATO’nun “açık kapı” politikasını başından beri desteklemiştir. Bu bağlamda Bulgaristan, Romanya, Slovenya, Slovakya, Estonya, Litvanya ve Letonya'nın 29 Mart 2004 tarihi itibarılla NATO'ya katılmalarını memnuniyetle karşılamıştır. İttifak tarihindeki en büyük genişlemeyi teşkil eden bu durum, Avrupa-Atlantik alanının bütününde güvenlik ve istikrarın daha da pekişmesine katkıda bulunmuştur. Yeni üyelerin İttifak'a katılımları, aynı zamanda özgür ve birleşik Avrupa'nın oluşturulmasına yönelik ortak amaca ulaşılmasına hizmet etmiştir. Türkiye, Avrupa-Atlantik ve Avrupa kurumlarının, kalıcı barışı, istikrarı ve refahı sağlamak amacıyla Balkanlar bölgesini kucaklaması ve bölgenin çok çeşitli tarihi mirasını Avrupa kültür ve medeniyetinin kurucu unsurları olarak kabul etmesi zamanının geldiği inancıyla, Adriyatik Şartı ülkelerinin (Arnavutluk, Makedonya, Hırvatistan) NATO üyeliklerini desteklemiştir. ${ }^{26}$

Türkiye; Makedonya'nın üyeliğini Balkan politikaları kapsamında değerlendirmektedir. Bu ülkede ortaya çıkacak herhangi bir sorun jeopolitik konumu itibariyle bölge ülkelerini de içine alacak ve bölgede ciddi huzursuzluklara neden olacaktır. Bölgeyle hem tarihi hem de jeopolitik yakınlığı bulunan Türkiye de bu huzursuzluktan doğrudan etkilenecektir. Bu yüzden Türkiye'nin Balkan politikalarının incelenmesi Makedonya'nın üyeliğine verdiği desteğin anlaşılmasını sağlayacaktır.

Türkiye'nin istikrar ve refahın kalıcı olarak tesisini hedefleyen Balkanlara yönelik politikası Başbakan Prof. Dr. Ahmet Davutoğlu'nun formülasyonuyla dört ana unsura dayanmaktadır: Bunlar "herkes için güvenlik", "yüksek

\footnotetext{
${ }^{22}$ Arı ve Pirinççi, a.g.e., s.17.

${ }^{23}$ Kader Özlem, a.g.e., s.35.

${ }^{24}$ Caner Sancaktar, "Makedonya'nın NATO'ya Üyelik Süreci ve Yunanistan'ın “ísim Vetosu”"

http://www.tasam.org/trTR/Icerik/100/makedonyanin_natoya_uyelik_sureci_ve_yunanistanin_isim_vetosu ( (22.12.2008)

${ }^{25} \mathrm{http}$ ://www.gundemkibris.com/abd-nato-uveligi-yolunda-makedonyayi-desteklevecek-84964h.htm (14.07.2014)

${ }^{26}$ Alıntılayan Burak Tangör, Avrupa Güvenlik Yönetişimi Bosna, Kosova ve Makedonya Krizleri , Ankara, Seçkin Yayıncılık 2008, s.167
}

BARIŞ ARAŞTIRMALARI VE ÇATIŞMA ÇÖZÜMLERi DERGisi http://dergi.cicr.org.tr/ 
düzeyli siyasi diyalog", "karşılıklı ekonomik bağımlılık” ve "bölgenin çok etnikli, çok kültürlü ve çok dinli sosyal dokusunun muhafazası"dır. Türkiye'nin, Balkan politikası bu bağlamda "bölgesel sahiplenme" ve "kapsayıcılık" ilkelerini esas almaktadır. "Herkes için güvenlik" zira, hiçbir Balkan toplumunun Avrupa-Atlantik güvenlik şemsiyesinin dışında bırakılmaması gerektiğine kuvvetle inanıyoruz. Balkanlarda bazı toplumlar kendilerini güvende hissederken, diğerinin dışlanması yeni istikrarsızlık ve çatışmaları beraberinde getirme riskini taşımaktadır. Balkan toplumları birbirleri ile çok yakın bir diyalog içinde olmalıdırlar. Bu ancak üst düzey temas ve diyalogun sürekli kılınması ile mümkün olacaktır. Liderler ne kadar çok bir araya gelirlerse toplumların içinde var olan önyargılar o kadar kolay yıkılacak ve başka ülkeler için gündelik hayatın ayrılmaz bir parçası olan temas ve ziyaretler olağan hale gelebilecektir. Balkanlarda ülkeler arası ekonomik ilişkiler canlandırılmalıdır. Şu andaki durum olması gerekenden hayli uzaktır. Komşu ülkelerin birbirlerine olan ekonomik bağımlılığı arttıkça, çatışma riskleri ters orantılı olarak azalacaktır. ${ }^{27}$ Görüldüğü gibi Türkiye bölgenin huzur ve güvenliğine son derece önem vermekte ve politikalarını buna göre şekillendirmektedir.

Tarihi olarak bakıldığında; Makedonya'nın diğer Yugoslav Cumhuriyetlerinden önemli bir farklılığ yayılmacılığın (irredantizm) hem öznesi hem de nesnesi olmasıydı. Tıpkı Makedon milliyetçiliğinin tüm Makedonları tek bir çatı altında toplamak için Pirin ve Ege Makedonya'sında hak iddia etmesi gibi, Bulgar ve Yunan milliyetçiliği de Büyük Bulgaristan ve Büyük Yunanistan projeleri için Makedonya’ya açılmak istiyorlar, Makedonya topraklarında hak iddia ediyorlardı. Sirp milliyetçilerinin Makedonya'y1 "Güney Sırbistan" olarak kabul etmesi, sorunu daha da karmaşık hale getiriyordu. ${ }^{28}$ Tüm bu karmaşa içersinde diğer ülkelere kıyasla kan dökülmeden bağımsızlığını kazanmayı başaran Makedonya günümüze kadar bu sorunların bir kısmını komşularıyla iyi ilişkiler kurarak çözmeyi başarmıştır. Bu sorunları çözmesine rağmen Yunanistan'la isim sorununu günümüze kadar çözememiştir. Bunun yanısıra içindeki etnik azınlıklar nedeniyle de diğer ülkelerle sorun yaşama potansiyelini hala taşımaktadır. Bu yüzden bu ülkenin istikrarı son derece önemlidir ve bu istikrar ancak NATO üyeliği sayesinde gerçekleşecektir.

Türkiye, Makedonya Cumhuriyeti'nin bağımsızlık ilanıyla beraber ülkeyi kendi ismi ile tanımıştır. Nitekim bu sebeple Makedonya'yı Eski Yugoslav Cumhuriyeti Makedonya ismiyle (FYROM) tanıyan NATO teşkilatına ait ve içinde Makedonya geçen tüm belgelerde metinde "FYROM" kısaltması geçerken belgenin sonundaki bir dipnotta Türkiye'nin ve diğer NATO üyeleri ABD, Arnavutluk, Bulgaristan, Estonya, Hırvatistan, İsveç, İzlanda, Kanada, Litvanya, Macaristan, Norveç, Polonya, Romanya ve Slovakya ile birlikte Makedonya'yı anayasal ismi ile tanıdığı ayrıca belirtilmiştir. ${ }^{29}$ Türkiye Makedonya'nın bağımsızlığını ivedi bir şekilde tanımakla kalmamış, bunun yanında kısa süre dünya ekonomik düzenine entegre olabilmesi içinde ciddi bir çaba göstermiştir. Buna göre 2000'li yıllara değin birçok işbirliği anlaşması imzalamış ve yürürlüğe sokmuştur. ${ }^{30}$

Türkiye'nin Makedonya'nın NATO üyeliğine destek vermesinin bir diğer nedeni ise bu ülkede yaşayan Türklerdir. Türkiye bu Türklerin korunmasını da bölge politikaları açısından değerlendirmektedir. Türkiye ve diğer Balkan ülkeleri halkları arasında önemli bağlar mevcuttur. Çeşitli Balkan ülkelerinde soydaş toplulukları yaşamaktadır. Diğer yandan, ataları, ebeveynleri ve/veya kendileri Balkanlardan değişik bölgelerinden Türkiye'ye göç etmiş vatandaşlarımız bulunmaktadır. Bu nedenle, Balkanlar'da ortaya çıkan bunalımlar, başta Türkiye'ye yönelik mülteci akımına yol açması olmak üzere, Türkiye bakımından önemli sonuçlar doğurabilmektedir. ${ }^{31}$

Günümüzde Makedonya Türkleri ülkenin geneline yayılmış ekonomik sıkıntılardan başka Türkçe eğitim konusunda da sorunlarla karşılaşıyor, asıl zorluğu ise milli aidiyet belirleme konusunda yaşıyor ve Arnavutluk ile Makedonlar arasında sıkışıp kalıyorlar. Politik anlamda ellerini güçlü tutmak isteyen Makedonyalı Arnavutlar Türk nüfusu kendi sayılarına dâhil etmek isterken benzer bir gerekçeyle aynı eğilimi Makedonlar da gösteriyor. ${ }^{32}$

\footnotetext{
27 Büyükelçi Hakan Okçal, Balkanlar ve Türkiye, Ankara Üniversitesi Rektörlüğü’nde Gerçekleştirilen GAMER Konferansı Konuşması, 14 Ekim 2011, GAMER, I, 1 (2012) s. 197-207.

28 INAF, The Republic of Macedonia, The Rising Sun in the Balkans, İstanbul, 1993, ss. 8-12'dan İrfan Kaya Ülger, Yugoslavya Neden Parçalandı Balkan Dramının Perde Arkası,Ankara, Seçkin Yayıncılık 2003, ss.129,130.

29 Mevlüt Tuğrul Görgün (Haz.), Makedonya Ülke Raporu, T.C. Başbakanlık Dış Ticaret Müsteşarlığı Ihracatı Geliştirme Etüd Merkezi, Ankara, 2011, s. 2.

30 Hatipoğlu, M. Murat, “Kuruluşundan Günümüze Makedonya Cumhuriyetinin Dış Politikası ve Balkan Ülkeleriyle İlişkileri (1991- 2000)", Balkan Diplomasisi, Der. Ömer E. Lütem, B. Demirtaş Coşkun, Avrasya Stratejik Araştırmalar Merkezi Yay., Ankara 2001, s.179'dan . Galip Çağ “Dağılan Yugoslavya'nın Ardından Makedonya ve Türkiye” Çankırı Karatekin Üniversitesi Uluslararası Avrasya Strateji Dergisi 1(1): 197216, s.209.

${ }^{31}$ Türkiye Cumhuriyeti Dışişleri Bakanlığı, “ Balkan Ülkeleri İle iliş̧kiler” http://www.mfa.gov.tr/balkanlar ile-iliskiler.tr.mfa

32 Gözde Yaşın Kılıç, “Kosova'da Türkçe'nin Mücadelesi” , Cumhuriyet Strateji, 2 Ekim 2006, sayı118,ss.20-21'dan Bilgin Çelik, Dağılan Yugoslavya Sonrası Kosova ve Makedonya Türkleri, 2. Baskı, İstanbul, Gürer Yayınları, 2013, s.138
} 


\section{Asiye Şimşek}

Makedonya'da Makedonlar nüfusun \%67'sini oluştururken, Arnavutlar \%25'lik bir oranla en kalabalık azınlık grubudur. ${ }^{33}$

Bilgin ÇELIKK Makedonya Türklerinin yaşadığı sıkıntıları ve Türkiye'nin bu konuda yapması gerekenleri kitabında şöyle özetlemiştir: "Makedonya Türkleri başlangıçta Makedon milliyetçiliğinin baskısı altında iken zamanla yükselen Arnavut milliyetçiliğinin etkisi ve baskısı altında kalmışlardır. Makedonya'nın AB üyeliği için başlattığı demokratikleşme süreci ülkede nispeten daha istikrarlı bir havanın doğmasına yol açmıştır. Buna karşılık endişe kaynağı olarak ortada duran en önemli konu Kosova'nın bağımsızlığı ihtimalinin Makedonya üzerinde yaratacağı etkilerdir. Makedonya Arnavutlarının böyle bir gelişme karşısındaki tutumları ve dolayısıyla bunun Türkler üzerinde yaratacağı etkiler belirsizliğini korumaktadır. Türkiye'nin Kosova ve Makedonya'ya ve buradaki Türklerine mevcut sisteme entegre olmaları yönünde vereceği destek bu açıdan anlamlı olacaktır. Milliyetçi fikirleri körüklemeksizin ve fetihçi zihniyetten uzak bir yaklaşım ile sadece Türklere dönük olarak değil tüm Balkanları kapsayacak barışçı bir çaba bölgenin geleceğini olumlu yönde etkileyecektir. Eğer Balkanlarda aşırı milliyetçilik törpülenebilirse ve belli bir uzlaşma sağlanabilirse Kosova ve Makedonya'da yaşayan Türkler açısından oldukça olumlu bir ortamın doğacağı açıktır. Türkiye'nin Makedonya ve bağımsızlığını yeni kazanan Kosova ile iyi ilişkiler kurması, dostluk ve işbirliğini geliştirmesi hem bölge açısından hem de bölgede yaşayan Türkler açısından çok önemli yararlar sağlayacaktır.",34

\section{Türkiye ve ABD’nin Kesişen ve Ayrılan Balkan Politikaları Açısından Makedonya’ya NATO Üyeliği İçin Verdikleri Desteğin Kıyaslanması}

1990'larda Türkiye ve ABD’nin çıkarları Balkanlar'da neredeyse tamamen kesişmiştir. Bunun nedeni her iki ülkenin de Balkanlarda benzeri çıkar ve hedeflere sahip bulunmaları ve aynı ülke ve grupları desteklemeleriydi. ABD’nin bu dönemde Balkanlarda en çok işbirliği yaptığı ülke Türkiye olurken, Türkiye bu işbirliği sayesinde bu bölgede daha fazla etkinlik sahibi olabilmiştir. Bu işbirliği, Türkiye ve ABD'nin Bosna-Hersek'teki savaşa müdahalenin zamanlaması konusundaki görüş ayrılıkları dışında, genelde bölgedeki hemen her gelişmede tam bir çıkar birliği içinde sürmüştür. Yalnız bölgedeki askeri önlemler çerçevesinde değil, diplomatik girişimler ve bölgesel işbirliği örgütlenmesi gibi konularda da Türkiye ve ABD dayanışma içinde olmuşlardır. ${ }^{35}$

İki ülkenin çıkarları bazı alanlarda kesişse de bölgeye bakış açılarında yer yer farklılıklar gözlenmiştir. Her şeyden önce Türkiye'nin bölgeyle tarihi, dini ve kültürel yakınlığı vardır. ABD’nin ise bölgeye duygusal açıdan bakmasını gerektirecek derecede yakınlığı yoktur.

Türkiye'nin bölgeyle tarihi yakınlığg Osmanlıdan gelmektedir. Yarımadaya adını veren Osmanlı fethi, bölgenin yaşadığı en uzun siyasal birlik dönemini başlatmıştır. Osmanlıların geri çekilişinin ardından gelen yüzyıl boyunca yarımadanın yeni siyasal parçalanmasına tanık olundu, ama yeni ülkeler, Balkanlar'ın sürekli periferi statüsünde bulunduğu Avrupa'yla ekonomik, sosyal ve kültürel bütünleşme dalgalarını yaşadı. ${ }^{36}$

Türkiye'deki Türk-İslam sentezcileri; Türkiye'nin, yakın çevresinde meydana gelen, Yugoslavya'nın parçalanması, SSCB'nin dağılması, Kafkasya'da yaşanan kargaşa, Körfez Savaşı gibi altüst oluşlardan sonra, kendini bölgesel güç olarak kabul ettirme isteğinin ideolojik temellerini atmayı başardılar.Türk-İslam sentezi, halkın gözünde, Bosnalılar ve Arnavutlar bir zamanlar Osmanlı ve halen Müslüman olduklarına göre, Türk olup olmamalarının fazla bir önem taşımadığı, Çeçen, Abaza, Kabarda, Balkar ve öbür Kafkas halklarından hangilerinin Türk olduğuna çok da aldırış etmemek gerektiği, Gagavuzların ise türk oldukları sürece Ortodoks olup olmamalarının fark etmediği, kısacası, Osmanlı İmparatorluğu'nun varisi olarak Türkiye'nin çevresiyle ilgilenmek için yepyeni nedenlerinin bulunduğu anlamına geliyordu. 1992 İlkbaharı'nda Türkiye Cumhuriyeti'nin başbakanı, Türkiye'nin nüfuz bölgesinin Adriyatik’ten Çin Denizi'ne uzandığını ilan etti. Bu bölgenin tarih boyunca hiçbir zaman barış içinde birlikte yaşanılan bir bölge olmadığı, genellikle tek bir gücün hakimiyetine girdiği doğrudur. Zaten ne Yunanistan'ın, ne Bulgaristan'ın ne de Surbistan'ın Türkiye'nin Balkan Müslümanlarına gösterdiği ilgiye olumlu olumlu baktıkları söylenebilir. Ancak SSCB’nin çökmesiyle Balkanlar'da meydana gelen boşluğu doldurmak üzere Türkiye'nin harekete geçmesi, tıpkı Almanya'nın aynı nedenlerle Doğu Avrupa'ya yönelmesi gibi engellenemezdi. ${ }^{37}$ Görüldüğü gibi Türkiye'nin bölgeyle yakın bağları dolayısıyla bölgeyle ilgilenmesi hayati derecede önemlidir.

\footnotetext{
33 Irfan Kaya Ülger, Yugoslavya Neden Parçalandı Balkan Dramının Perde Arkası,Ankara, Seçkin Yayıncılık 2003, s.127.

34 Bilgin Çelik, Dağılan Yugoslavya Sonrası Kosova ve Makedonya Türkleri, 2. Baskı, İstanbul, Gürer Yayınları, 2013 ss.170,171

${ }^{35}$ Ahmet Yıldız, a.g.e., ss.92-93.

${ }^{36}$ Maria Todorova, Balkanları Tahayyül Etmek, 4. Baskı, İstanbul, illetişim Yayınları, 2013, s.

${ }^{37}$ Stefanos Yerasimos, Milliyetler ve Sınırlar Balkanlar, Kafkasya ve Ortadoğu,6. Baskı, i̇stanbul, 2010, s.31
}

BARIŞ ARAŞTIRMALARI VE ÇATIŞMA ÇÖZÜMLERI DERGisi http://dergi.cicr.org.tr/ 
ABD açısından ise Balkan bölgesinin anlamı şöyle açıklanabilir: 11 Eylül 2001 sonrasında ABD dış politikasında radikal değişiklikler yaşanırken; Washington yönetimi açısından dış politik vizyon Afganistan ve Irak konularında yoğunlaşmış ve Balkanlar konusu yeniden ikinci plana düşmüştü. Aslına bakılırsa, ABD için Balkanlar, Soğuk Savaş sonrası dönemde öncelikli bir alan olmamış; zamanla oluşan bazı stratejik çıkarları gereği (örneğin NATO ve bölgedeki Arnavutlar gibi) bölgeyi bir sıçrama tahtası olarak kullanmıştı. Dolayısıyla, Makedonya krizi sonrası Washington yönetimin ülke üzerinde çok fazla etkili olmadığı görülse de; gerek ülkedeki Arnavutların silahsızlandırılması gerek Üsküp'ün gerekli reformları yapması bağlamında yardımcı bir görev üstlenmiştir. Bu kapsamda NATO tarafından 26 Ağustos 2001'de başlatılan Zorunlu Hasat Operasyonu, çeşitli adlar altında Mart 2003'e kadar sürüp, Arnavut militanların elindeki silahlar toplanırken; ABD bu operasyonlara asker göndermemiş; Türkiye ise, mikro ölçekte katılım göstermiştir. ${ }^{38}$

Türkiye ve ABD’nin politikalarını Makedonya özelinde incelediğimizde ise yine birçok alanda hemfikir olduklarını görebiliriz. ABD, Makedonya'nın Yunanistan'la isim sorunun çözülmesi anlamında da taraflara sıkça çağrıda bulunmuştur. Bağımsızlığın ilanından beri Makedonya’ya uluslararası alanda siyasi, ekonomik ve askeri açıdan destek olan Türkiye, bu ülkeyi Yugoslavya'dan ayrılan diğer ülkelerle eş zamanlı olarak anayasal ismiyle tanımış ve her alanda ilişkilerini geliştirmiştir. Öyle ki, Üsküp-Ankara eksenindeki olumlu ilişkiler, zaman zaman ülkedeki Türkleri ve Arnavutları şaşırtmıştır. Zira Türkiye Makedonya'nın toprak bütünlügünnü savunurken; geleneksel olarak izlediği Balkanlar'daki Türk ve/veya Müslüman azınlıkları bulunulan ülkenin içişlerine karışma aracı olarak kullanmama politikasını sürdürmüştür. Bu noktada, Türkiye'nin Makedonya'ya yönelik politikasının; Makedonya’nın bağımsızlığı ve toprak bütünlüğü ekseninde yoğunlaştığı görülmektedir. Ekim 1997'de Türk Dışişleri Bakanı İsmail Cem'in Üsküp ziyaretinde ifade ettiği üzere, Ankara yönetimi "Makedonya'nın istikrarını Balkanlar'da barışın ön koşulu olarak" görmekteydi. ${ }^{39}$ Aynı şekilde ABD de Makedonya'yı uluslararası alanda Türkiye gibi anayasal adıyla tanıyamasa da (FYROM) adıyla tanımıştır. Uluslararası kuruluşlara üyeliğine destek vermiştir. Balkanların istikrarı için bu ülkeyi önemli görmüş desteğini sürdüreceğini de açıklamıştır. NATO'nun genişleme politikası kapsamında, Makedonya'nın NATO üyesi olmasını öncelikleri arasında görmüştür. Makedonya'da yaşayan farklı milletler Makedon ve Arnavut halklarının bir arada ve bütünleşmiş bir şekilde yaşaması için her iki tarafın da özverili şekilde çalışması gerektiğini vurgulamıştır. ${ }^{40}$

\section{SONUÇ}

Makedonya jeopolitik konumu ve içersinde yaşayan etnik unsurlar nedeniyle bölge için potansiyel tehlike ihtimalini her zaman bünyesinde barındırmaktadır. Bağımsızlık ilanından itibaren hem dışarda komşularıyla hem de kendi içinde yaşadığı problemleri ciddi çatışmalara döndürmek istemeyen Makedonya çözümü daima diplomatik yollarda ve özellikle uluslararası kuruluşlara üyelikte aramıştır. Bu açıdan NATO üyeliği bulunmaz bir firsat sunmuştur Makedonya'ya. Bu kuruluşa üye olması askeri savunma açısından ülke için çok önemlidir. Çünkü NATO kendi üyelerinden birine yapılan saldırıyı tüm üyelerine yapılmış saymakta ve o ülkeye savunma açısından çok ciddi imkanlar sunmaktadır.

Türkiye ve ABD Makedonya'da herhangi bir sorun çıkmasını istememektedir. Çünkü bu ülkede ortaya çıkacak bir sorun bölgenin geneline yayılma ihtimali taşımaktadır. Eğer burdaki sorun bölgenin geneline yayılırsa bölgeyle tarihi ve jeopolitik yakınlığı bulunan Türkiye doğrudan etkilenecektir. ABD ise bölgeyi hayati çıkar alanı olarak görmemekte fakat bu bölgede sorun çıkması ihtimalinde NATO üyeliği, bölgesel jandarma rolü üstlenmesi ve Rusya'nın yayılma tehlikesi nedeniyle müdahale etmek zorunda kalacaktır. Bu da sorunlu ve stratejik açıdan daha önemli gördüğü ortadoğu ve kafkaslar gibi bölgelerle ilgilenmesinin önünde engel teşkil edecektir. İki ülke de askeri açıdan Makedonya'nın huzurunun garantisini NATO'nun vereceğine inanmaktadır. $\mathrm{Bu}$ nedenle hem Türkiye hem ABD gerekçeleri farklı da olsa Makedonya'nın NATO üyeliğİne sonuna kadar destek vermektedirler.

\footnotetext{
38 Kader ÖZLEM, a.g.e., s.36.

39 Şule Kut, Balkanlar'da Kimlik ve Egemenlik, İstanbul Bilgi Üniversitesi Yayınları, İstanbul, 2005'dan Kader ÖZLEM, a.g.e., s.212.

40 http://www.abhaber.com/abd-nato-uyeligi-yolunda-makedonyayi-destekleyecek (14 Temmuz 2014)
} 


\section{KAYNAKÇA}

\section{KITAPLAR}

Akçay, B., Göçmen, İ. (Ed.) (2012). Avrupa Birliği; Tarihçe, Teoriler, Kurumlar ve Politikalar. Ankara: Seçkin. Çelik, B. (2013). Dağılan Yugoslavya Sonrası Kosova ve Makedonya Türkleri. İstanbul: Gürer.

Tangör B. (2008). Avrupa Güvenlik Yönetişimi Bosna, Kosova ve Makedonya Krizleri. Ankara: Seçkin.

Todorova M. (2013). Balkanları Tahayyül Etmek. İstanbul: İletişim

Ülger İ. K. (2003). Yugoslavya Neden Parçalandı Balkan Dramının Perde Arkası. Ankara: Seçkin.

Yerasimos S. (2010). Milliyetler ve Sinırlar Balkanlar, Kafkasya ve Ortadoğu. İstanbul:

\section{MAKALELER}

Arı, Tayyar ve Pirinççi, Ferhat, "Soğuk Savaş Sonrasında ABD’nin Balkan Politikası”, Alternatif Politika, Cilt.3, Say1.1, Mayıs 2011.

Özlem, Kader, “Soğuk Savaş Sonrası Dönemde ABD’nin ve Türkiye’nin Balkanlar Politikalarının Bosna Hersek, Kosova Ve Makedonya Krizleri Örneğinde İncelenmesi”, Trakya Üniversitesi, Balkan Araştırma Enstitüsü,?.

Uğrasız, Bülent, “ABD’nin Soğuk Savaş Sonrası Balkan Politikası”, Dokuz Eylül Üniversitesi Sosyal Bilimler Enstitüsü Dergisi, Cilt:6 Sayı:1,2004.

Çağ, Galip, “Dağılan Yugoslavya’nın Ardından Makedonya ve Türkiye”, Çankırı Karatekin Üniversitesi Uluslararası Avrasya Strateji Dergisi 1(1): 197-216.

Gürkaynak, Muharrem, “İkinci Dünya Savaşı Sonrasında Avrupa'da Savunma ve Güvenlik”, (Yayımlanmış doktora tezi, Danışman Prof. Dr. Ersin Onulduran, Ankara Üniversitesi Sosyal Bilimler Enstitüsü, 2004).

Doğan, Nejat "Nato'nun Örgütsel Değişimi, 1949- 1999:Kuzey-Atlantik İttifakından Avrupa-Atlantik Güvenlik Örgütüne”, Ankara Üniversitesi, SBF Dergisi, 60-3.

Beriş, Yakup ve Gürkan, Aslı (Haz.), Türk- Amerikan İlişkilerine Bakış:Ana Temalar ve Güncel Gelişmeler, TÜSİAD ABD Temsilciliği Değerlendirme Raporu-Temmuz 2002.

Yıldız, Ahmet, “Türkiye'nin Balkanlarda Etkin Bir Politika İzlemesinin Avrupa Birliği ile Olan İlişkilere Etkileri”, (Yayımlanmış Yüksek Lisans Tezi, Danışman :Yrd.Doç.Dr. Ülkü Varlık, Trakya Üniversitesi, Sosyal Bilimler Enstitüsü Ocak, 2006).

Okçal, Hakan, Balkanlar ve Türkiye, Ankara Üniversitesi Rektörlüğü’nde Gerçekleştirilen GAMER Konferans1 Konuşması, 14 Ekim 2011, GAMER, I, 1, 2012.

Görgün, Mevlüt T. (Haz.), Makedonya Ülke Raporu, T.C. Başbakanlık Dış Ticaret Müsteşarlığı İhracatı Geliştirme Etüd Merkezi, Ankara, 2011.

Çomak, Hasret ve Ülger, İrfan K., "Balkanlarda Siyasi İstikrar ve Geleceği”, BİLGESAM, Rapor NO:14. 
Makedonya'nın Nato Üyeliğinin Türkiye ve ABD Desteği Kapsamında Tartışılması

\section{INTERNET KAYNAKLARI}

http://www.mfa.gov.tr/nato-tarihce.tr.mfa

http://www.milliyet.com.tr/ozel/nato/zeynep.html

http://www.mfa.gov.tr/ii_-nato-ve-turkiye_nin-guncel-nato-konularina-iliskin-gorusleri.tr.mfa

http://www.euractiv.com.tr/politika-000110/article/vahit-erdem-soguk-savas-sonrasi-natonun-deigisim$\underline{\text { surecinde-genisleme-politikasi-011490 }}$

http://www.tasam.org/trTR/Icerik/100/makedonyanin_natoya_uyelik_sureci_ve_yunanistanin_isim_vetosu

http://www.gundemkibris.com/abd-nato-uyeligi-yolunda-makedonyayi-destekleyecek-84964h.htm

http://www.mfa.gov.tr/balkanlar_ile-iliskiler.tr.mfa

http://www.abhaber.com/abd-nato-uyeligi-yolunda-makedonyayi-destekleyecek 